\title{
Re-Emerging Inequality: Narrow Economic Gaps between Immigrant and Non-Immigrant Offspring Widen Over the Life Course
}

\author{
Nino José Cricco* \\ *Harvard University \\ ncricco@g.harvard.edu \\ Working Paper \\ Last Updated: October 6, 2021
}

\begin{abstract}
Scholarship investigating economic disparities between immigrants and non- immigrants posits that immigrants' income disadvantages decline over time and across generations, but life course approaches contend that inequalities between groups widen as individuals age. Using data from the NLSY 1997, I show that the relative economic positions of children of Latino immigrants shift over the life course when compared to children of White and Black non-immigrants. Average family income among children of Latino immigrants resembles that of the children of White non-immigrants at age 25. But children of White non-immigrants experience faster income growth as they age, tending to outrank the children of Latino immigrants by the early thirties. Accounting for intergenerational legacies of disadvantage shows that children of Latino immigrants initially outrank the children of White non-immigrants from similar economic backgrounds - an "intergenerational premium" - but this intergenerational premium erodes with age. Contra the segmented assimilation hypothesis, children of Latino immigrants maintain favorable positions relative to children of Black non-immigrants regardless of parental income. These findings suggest that the temporal patterns of economic convergence between immigrants and non-immigrants are not linear. Though intergenerational progress is substantial, the life course is a critical period through which inequalities can be made anew.
\end{abstract}

Keywords: Immigration, Life Course, Racial and Ethnic Inequality, Intergenerational Mobility, Intragenerational Mobility 


\section{Introduction}

The persistence of economic disparities between immigrants and non-immigrants over time is a key area of empirical and theoretical debate. Theoretical approaches in economics and sociology draw on human capital theory and acculturation to emphasize steady progress across generations, predicting that immigrant offspring's incomes will converge with those of non-immigrants over time. Others counter that, due to the increasingly segmented nature of the United States' ethnoracial stratification system (Portes and M. Zhou, 1993) or the intergenerational persistence of lower levels of human capital (Borjas, 1985 Borjas, 1989) socioeconomic convergence will be stalled across generations.

Prior research on children of immigrants' socioeconomic outcomes largely focuses on comparisons at a single point in time (or a time-averaged observational period) once these individuals reach adulthood. These approaches implicitly characterize social mobility across generations as a step-wise process in which children's socioeconomic position as adults can be compared to that of their parents or their peers. While suitable for examining achieved characteristics that remain largely constant over adulthood, like educational attainment, these step-wise approaches yield an incomplete picture of immigrants' social mobility over time for outcomes that vary over the life courses, such as occupational attainment, earnings, or economic well-being.

Drawing on insights from the demographic and stratification literatures on income dynamics over the life course, I argue that life course variations in economic attainment have important implications for assessing immigrants' mobility patterns. Economic trajectories vary systematically by race and ethnicity (Cheng, 2014), suggesting that inequalities between groups (such as immigrant compared to non-immigrant offspring) can widen (or diminish) over time as individuals age.

Furthermore, these life course differences in economic attainment can impact estimates of intergenerational income persistence. Income persistence tends to be larger when sons' earnings are measured at older ages (Haider and Solon 2006; Mazumder 2005). The relationship between sons' and fathers' earnings may not be constant across the life course; thus, any differences in intergenerational income persistence between groups might also 
vary across the life course. This is consequential for assessments of immigrants' intergenerational mobility because canonical models of intergenerational persistence suggest that group differences in income distributions in the long term are largely determined by group differences in children's income conditional on their parents' income (Becker and Tomes, 1979; Chetty et al., 2020; Duncan et al., 1968). These models predict that if, conditional on parental income, immigrant descendants have similar (or higher) incomes than non-immigrant offspring, then income disparities by immigrant origin will decline across generations. However, these models assume that the relationship between parental income and children's income is static over the life course: they do not consider whether intergenerational gaps change within generations, shaping inequality between groups over time.

I focus on relative economic mobility over the life course and compare children of Latino immigrants to the children of White and Black non-immigrants, contributing to theoretical debates on mobility among the children of immigrants by operationalizing economic position as a time-varying construct. Specifically, I ask two questions: are there income disparities between children of Latino immigrants and children of White and Black non-immigrants, and do they increase or decrease over the life course? What role do differences in economic background play in changing income gaps between children of Latino immigrants and children of White non-immigrants over the life course?

Using data from the National Longitudinal Surveys of Youth's 1997 cohort, I find that, in early adulthood, average family income is similar among the children of Latino immigrants and the children of White non-immigrants, and significantly higher than that of the children of Black non-immigrants. However, children of Latino immigrants have substantially lower rates of income growth than the children of White non-immigrants; thus, they tend to lose ground relative to children of White non-immigrants as they age. But the children of Latino immigrants in this cohort do not converge economically with children of Black non-immigrants, maintaining their favorable relative position through middle adulthood.

Compared to same-aged peers with the same parental income, children of Latino 
immigrants start off with higher income than children of both White and Black nonimmigrants. This intergenerational "premium" is consistent with research documenting higher average earnings rank conditional on parental income among children of immigrants than the children of non-immigrants (Abramitzky, Boustan, Jácome, et al., 2019). However, conditional on parental income, children of White non-immigrants in this cohort experience higher rates of relative income growth. Consequently, even though children of Latino immigrants have higher rates of upward intergenerational social mobility than children of White non-immigrants overall, this intergenerational premium erodes by the time this cohort reaches their mid-thirties. These results support theoretical perspectives contending that children of immigrants will experience upward mobility across generations. Yet, they also support the logic of segmented assimilation: though children of Latino immigrants maintain a favorable position relative to the children of Black nonimmigrants, their progress relative to children of White non-immigrants falls behind over the life course.

By showing that between-group differences in income conditional on parental income vary not only across, but within generations, I highlight the importance of the life course as a temporal dimension through which inequalities between immigrants and non-immigrants can broaden and be made anew. These intragenerational processes are a key dimension of immigrants' social mobility, with long-term implications for ethnoracial stratification in the United States (Bean and Tienda, 1988; Bonilla-Silva, 2004; Lee and Bean, 2007).

\section{Temporal Perspectives on Immigrants’ Economic At-}

\section{tainment}

Over time and across generations, immigrants tend to close economic gaps with nonimmigrants, both in recent and historical cohorts (Abramitzky, Boustan, Jácome, et al., 2019; R. Alba, Kasinitz, and Waters, 2011; Catron, 2020), though with some variations across groups and over generations (Telles and Ortiz, 2008; Ward, 2020). Some 
approaches to immigrant's socioeconomic mobility suggest immigrants are better positioned to improve upon their parents' position across generations than non-immigrants, as immigrant parents' earnings in the host country might not reflect their human capital. Because children of immigrants born and raised in the United States do not face similar issues of language competency (Warner and Srole, 1945), legal status, or imperfect skill transmission from origin to destination country (Abramitzky, Boustan, and Eriksson, 2014; Chiswick and Miller, 2009) as their parents, they are well-positioned to improve their economic positions (Warner and Srole, 1945), leading to the decline in ethnic distinctions across generations (R. D. Alba and Nee, 2009; Kasinitz et al., 2009).

Other approaches emphasize the persistence of economic disadvantage across generations or even "second-generation decline" (Gans, 1992), drawing attention to the changing structure of economic opportunity in the United States, the stratified nature of the United States' ethnoracial system, and changes in the composition of immigrant flows after the Immigration and Nationality Act of 1965. In particular, the segmented assimilation perspective (Portes and M. Zhou, 1993) argues that, although some children of immigrants follow the linear trajectory towards convergence with the "mainstream" (operationalized as White non-immigrants), others structurally assimilate into the "margins" of the host society (operationalized as the racialized, Black and Latino non-immigrants). This perspective suggests that improving upon their parents' position might be a harder task for children of immigrants than for children of (White) non-immigrants who do not face issues of racial discrimination in the labor market.

While assessing whether economic inequality between immigrants and non-immigrants changes over time across generations, these approaches do not explicitly consider how inequalities between immigrant and non-immigrant offspring can be widened (or narrowed) within generations. While they make opposite predictions regarding the extent to which children of immigrants will achieve upward mobility, both approaches implicitly characterize mobility as a step-wise process that compares children's outcomes to those of their parents at a single point in time (or a time-averaged observational period). In other words, either children of immigrants have improved upon their parents' position, or they have 
not. Or, when comparing children of immigrants to their peers, these approaches limit conclusions to assessments of whether children of immigrants fare better than, similar to, or worse than the children of non-immigrants at the time of measurement.

These comparisons are unproblematic for outcomes that remain static over the life course. Comparing educational attainment between immigrant and non-immigrant offspring, for example, only requires one to assume that individuals have completed their education by the time of measurement (or that educational attainment completed by a given age constitutes a meaningful construct). Economic outcomes, however, are not constant over the life course: they vary over time. For example, immigrant offspring might start off at similar economic positions as their peers, but their fortunes might increasingly diverge as they age. When applied to outcomes that vary over time (such as earnings, self-rated health, labor force participation, or occupational attainment), approaches that assume a static outcome among later generations can obscure the temporal dynamics of inequalities that emerge over the life course. In this paper, I foreground these life course dynamics as an under-examined, yet critical temporal process for understanding immigrants' economic mobility.

\section{How do Economic Inequalities Shift Over the Life}

\section{Course?}

Research on immigrants' economic mobility recognizes the importance of life course dynamics in the first generation, for whom an initial gap in earnings with non-immigrants is predicted to close with time spent in the host country (e.g. Abramitzky, Boustan, and Eriksson, 2014; Catron, 2016; Chiswick and Miller, 2009; Han, 2020; Lubotsky, 2007; Villarreal and Tamborini, 2018) but rarely considers changes over the life course in the second generation. Usually, researchers assume the point at which income is observed in the cross-section reflects individuals' "permanent income." While some researchers seek to better approximate permanent income by averaging income across multiple years of observations (Abramitzky, Boustan, and Eriksson, 2014; Ward, 2020), they do not usually 
consider variability across years a matter of substantive interest.

These assumptions are problematic because the life course is a central dimension through which inequalities between people and groups can increase (or decrease) over time (Blau and Duncan, 1967; Bloome and Furey, 2020; Cheng, 2014; DiPrete and Eirich, 2006; Jarvis and Song, 2017). Cumulative advantage, whereby individual or group advantages in resources (such as income or occupational position) grow over time, is a key mechanism in the production of between-group inequality (Cheng, 2014, DiPrete and Eirich, 2006). These cumulative advantages can operate both within the life course and across generations. For example, in the classic status attainment model in sociology, Blau and Duncan, 1967 sketch out a model of intergenerational persistence in parents and children's positions in the status hierarchy via the chained processes of educational attainment, school-to-work linkages, and career trajectories. Differences in educational attainment are an important driver of group-based inequality over the life course, as earnings among the college educated rise steeply relative to those with lower levels of educational attainment (Autor, Katz, and Kearney, 2008). But ethnoracial stratification is still pervasive within educational groups (Cheng, Tamborini, et al., 2019), and groupbased inequalities in economic outcomes can emerge even beyond initial inequalities in education. Focusing on career trajectories and comparing individuals with the same level of education, Tomaskovic-Devey, Thomas, and Johnson, 2005 argue that group-based inequalities emerge over the life course because racial discrimination limits human capital accumulation over time for Black and Hispanic men, limiting their earnings potential. Examining differences in wealth, Killewald and Bryan, 2018 find that though adjusting for intergenerational disadvantage substantially reduces the Black-White and HispanicWhite wealth gaps, differences in wealth-enhancing traits like income, marriage, and homeownership that emerge over the life course account for a growing share of the wealth gap as individuals age.

These findings illustrate that the life course can be a critical temporal dimension through which economic inequalities can emerge, even between groups that start off at similar positions in terms of their own income, level of education, or social origins. Moti- 
vated by these insights, I argue that understanding group-based differences in economic outcomes between immigrant and non-immigrant offspring over time requires examining income dynamics over the life course. I illustrate this approach by comparing how differences in average family income rank change over the life course among children of Latino immigrants and children of White and Black non-immigrants. Drawing on the idea that ethnoracial stratification in US labor markets can produce "segmented pathways and outcomes of incorporation" among children of immigrants (Portes and M. Zhou, 1993), I ask whether income disparities between children of Latino immigrants and children of White and Black non-immigrants increase (or decrease) over the life course.

These life course changes in income disparities between groups are consequential for assessments of long-run income gaps between groups over generations. Sociological (Duncan et al., 1968) and economic (Becker and Tomes, 1979; Chetty et al., 2020) models of intergenerational income persistence posit that group-level differences in the association between parents' and offspring's income are key determinants of group differences in income distributions over time. However, most studies examining intergenerational income persistence rely on single or time-averaged measures of income. While these studies can provide informative assessments of group differences in income persistence, a life course approach can help shed light on the temporal horizons through which these patterns of income persistence emerge.

\section{How Does Life Course Inequality Matter for Intergen- erational Mobility and Income Gaps Across Genera-}

\section{tions?}

Both group differences in the level of parental income and group differences in the relationship between parental and offspring income matter for group differences in income distributions over time. Duncan (1968) argues that Black families are doubly disadvantaged in that they are less likely to be advantaged and are less able to pass on advantages 
to their children than White families (Duncan et al., 1968). This point is echoed in Pfeffer and Killewald, 2019, who find that on average, Black children have less wealthy parents and are more likely to be downwardly mobile in wealth than similarly situated White children. Economic models predict that regardless of the initial magnitude of the income gap between two groups, income gaps would vanish across generations if there are no income differences between group members growing up in similarly situated households (Becker and Tomes, 1979; Chetty et al., 2020). In other words, these models predict that group-based differences in income distributions over time are largely determined by differences in children's income conditional on their parents' income (Becker and Tomes, 1979); Chetty et al., 2020 term this quantity the "intergenerational gap".

From this perspective, understanding whether income differences between immigrants and non-immigrants will persist in the long run requires examining whether immigrant offspring have lower or higher incomes than non-immigrant offspring conditional on parent income. If children of immigrants tend to fare better than their parental income alone would predict, then income gaps between immigrants and non-immigrants will tend to narrow across generations, even if the initial income gaps between immigrants and nonimmigrants are high. Economic research suggests that children of immigrants exhibit higher average incomes than children of non-immigrants with parents at the same position in the income distribution (Abramitzky, Boustan, Jácome, et al., 2019), an "intergenerational premium." Assuming that immigrant offspring exhibit an intergenerational premium (or, at least, not an intergenerational penalty) across generations, traditional models of intergenerational persistence suggest that earnings differences between immigrant and non-immigrant descendants will close over time.

This implication, however, rests on the assumption that the intergenerational premium observed in prior research holds across the life course (or at least until the second generation becomes parents themselves). Previous research finds that the intergenerational persistence of earnings varies substantially across the(Cheng and Song, 2019). Estimates of intergenerational income persistence are lower when earnings are measured earlier in life and larger when measured later in life (Mazumder, 2005). These findings 
suggest that the returns to parental resources grow over the life cycle, such that groups with higher levels of parental resources exhibit greater advantages over groups with lower levels of parental resources as they age.

The intergenerational mobility literature has discussed these life cycle patterns in intergenerational socioeconomic persistence in terms of bias when estimating a singlenumber measure that captures mobility rates across generations (Haider and Solon, 2006). But operationalizing economic position as a time-varying construct as opposed to a single summary measure frees us from interpreting life-cycle patterns as bias. Instead, it centers these life cycle patterns as a key temporal dimension through which economic inequalities between groups can widen and/or decline. These insights motivate a second set of questions concerning whether growing income gaps between children of Latino immigrants and children of White non-immigrants over the life course can be explained by differences in parental income. In other words, are differences in income growth between children of Latino immigrants and children of White immigrants attributable to different levels of economic background and the growing importance of economic background over the life course? Or do difference in incomes conditional on parental income between children of Latino immigrants and children of White non-immigrants widen as these individuals age?

\section{Data}

To answer these questions, I use data from the National Longitudinal Survey of Youth's 1997 cohort (NLSY97). NLSY97 respondents were drawn from nationally representative samples of individuals aged 12-18 in 1997 and surveyed annually up to 2011, and biennially since. The nationally representative nature of the sample, the frequency of data collection, and the beginning of the observational period - where youth are observed while co-residing with their parents (or guardians) — make the NLSY an ideal data source to capture income dynamics over the life course and the relationship between intragenerational and intergenerational mobility. Furthermore, the NLSY97 data include a contemporary cohort of children of immigrants who came to the United States in the 
aftermath of the Immigration and Nationality Act of 1965, which dramatically altered the composition of immigrants coming to the United States 1 .

Because the NLSY97 cohort is still in early adulthood at the latest period in which they are observed, my analyses focus on early adulthood. Focusing on early adulthood limits the inferences we can make about patterns over the entire life course. However, earnings growth is steepest during individuals' early careers (Cheng, 2014): as a result, I expect that this observational period will capture the main extent to which income gaps between groups grow over the life course, before income growth tapers off by middle adulthood. I conduct comparable supplementary analyses using data from the NLSY79: these analyses follow an earlier cohort through a similar period into retirement age (tables 13 and 14 in the appendix).

Although NLSY97 does not oversample immigrant populations, it oversamples Black and Latino respondents, providing sufficient sample sizes to compare income patterns across several groups. I illustrate how the dynamics of income mobility over the life course shape our understanding of immigrants' economic mobility relative to non-immigrants at the level of the ethnoracial group, focusing on children of Latino immigrants, the largest ethnoracial group among the children of immigrants in the data. I compare group-level differences in intragenerational income trajectories across three groups: children of Latino immigrants, children of White non-immigrants, and children of Black non-immigrants 2 , I restrict the analyses to individuals who were born in the United States. I identify the children of immigrants using indicators on their parents' country of birth 3 . The sample

\footnotetext{
${ }^{1}$ Other studies focusing on the children of post-1965 immigrants rely on more limited waves of data: while the Children of Immigrants Study (CILS) collects longitudinal data on the second generation beginning when they are youth, individuals are only aged 24 by the third and final wave, and the Immigrant Second Generation in New York (ISGMNY) and Immigration and Intergenerational Mobility in Metropolitan Los Angeles survey (IIMMLA) only collect data at a single point in time. While these data provide large samples of immigrant children and detailed information on national origin, the lower frequency of data collection make them less suitable for analyses that focus on income mobility over the life course.

${ }^{2}$ I exclude the Latino children of non-immigrants from the analysis because I cannot distinguish third from $4+$ generation Latinos, and generational status is likely an important source of systematic earnings variability among later generation Latino children of non-immigrants.

${ }^{3}$ Using the public use files, I use indicators for the number of parents born in a given region, which are computed by the BLS based on the restricted access variables labeling each parents' country of birth. I code an individual's parents as non-US born if that individual does not report having a parent born in a world region other than the US (Africa, Asia, Canada, Caribbean, Europe, Middle East, Mexico-Central America, and South America).
} 
sizes for children of immigrants from other ethnoracial groups are too small to provide reliable estimates, and are excluded from the analyses.

\section{Measures}

I use age-specific family income rank as the main dependent variable. Using income rank rather than absolute income highlights relative persistence in economic outcomes, consistent with the emphasis on relative comparisons in immigration (Abramitzky, Boustan, Jácome, et al., 2019) and intergenerational mobility scholarship (Bloome, Dyer, and X. Zhou, 2018; Breen, Breen Jr, et al., 2004; Chetty et al., 2020). This approach distinguishes growing between-group inequality due to overall increases in inequality from changes in individuals' relative positions in the income distribution over time. If life course inequalities operated exclusively via strict cumulative advantage, whereby everyone's family income grew exponentially from its baseline level, we would not observe changes in relative positions in the age-specific income distribution. Using an age-specific rank measure captures the extent to which, on average, individuals from different groups move up (or down) the family income distribution as they age, relative to their peers, netting out average income growth with age.

I use family income rather than personal earnings to better captures individuals' economic wellbeing relative to other members of their cohort (Bloome, Dyer, and X. Zhou, 2018; Bloome and Furey, 2020). Between-group variation in family income is shaped by group-level differences in not only individual earnings, but family arrangements (such as intergenerational co-residence, probability of co-residing with a partner, and probability that both partners work full-time), and differences in the probability of garnering income from different sources (such as business and farm income). Thus, family income better captures the myriad processes shaping group differences in economic well-being. Focusing on family income also allows me to examine both men and women in ways that account for joint decisions in labor supply among members of the household. Models analyzing men's hourly earnings yield similar results (see Table 8 in the appendix). 
Family income is the sum of the respondent's, their spouse/partner's, and co-resident family members' income in the prior year from several sources, including wage and salary income, business and farm income, several government programs, rental income and dividends from stocks and mutual funds, and other income sources. Individuals' total family incomes are ranked according to the age-specific family income distribution. Though I only include individuals with non-missing family income values in the analyses (88\% of the total sample), I impute family income for sample members with missing values before constructing the rank measure ${ }^{4}$.

I measure parental income with reports from the earliest five survey waves (19972001), averaging across all years in which parents reported income to reduce measurement error (Bloome, Dyer, and X. Zhou, 2018; Mazumder, 2005) 5. I then rank parental income across individuals according to where their parents fall in the (time-averaged) income distribution. $8 \%$ of the sample have missing data on parental income. For these individuals, I impute parental income via multivariate imputation by chained equations using the mice package in R (Van Buuren and Groothuis-Oudshoorn, 2011).

Table 1 shows total sample sizes, measures of average total family income, and agespecific income ranks at different age ranges. The average parental income rank among children of Latino immigrants in this sample is the 45th percentile, compared to the 59th and 36th percentiles among children of White and Black non-immigrants, respectively. On average, children of Latino immigrants start off in comparable positions in the income distribution to children of White non-immigrants in early adulthood (ages 25-28), with a difference in rank smaller than 1 percentile and an advantage of around 200 dollars in absolute family incomes. However, less than a decade after, at ages 33-36, the average relative position among children of Latino immigrants has fallen by about four percentiles, while the average relative position among children of White non-immigrants

\footnotetext{
${ }^{4}$ Supplementary analyses that adjust for need by dividing family income by the square root of family size before generating the income ranks yield similar conclusions. Though the effect sizes of the coefficients of interests are reduced when adjusting for family size, suggesting that family composition can be an important source of variation in economic wellbeing, the results are substantively similar in both sign and significance (see Table 6 in the appendix).

${ }^{5}$ The average number of parental observations among the Latino children of immigrants is 3.54 , compared to 2.55 and 2.46 for the White and Black children of non-immigrants, respectively.
} 
has climbed about 1.5 percentiles. This difference in relative rank at later stages translates to an average absolute difference of more than ten thousand dollars, compared to a five-hundred-dollar advantage at earlier ages. While average family income among children of Black non-immigrants increased over this period by about two thousand dollars, their average position in the age-specific income distribution declined by two percentiles. In the following sections, I illustrate analyses that test whether the average position of these groups in the age-specific income distribution changes in meaningful ways over the life course.

\section{Methods}

I use multilevel growth curve models (Raudenbush and Bryk, 2002) to analyze grouplevel differences in family income at baseline and family income growth over the life course between children of Latino immigrants and children of White and Black non-immigrants. I define the baseline point $\mathrm{t}$ as respondents' observations when they are aged 25 and observe respondents up to age $366^{6}$. I use the log of respondent's age to allow the age effect on income rank to be non-linear but monotonic: the substantive results are robust to different functional form specifications (linear, quadratic) of the relationship between age and income rank (see Table 9 in the appendix). All analyses use custom survey weights supplied by the NLS to account for the probability of selection into the sample and attrition over time, making the respondents who participated in any of the years in which data were collected nationally representative $7^{7}$

The baseline model involves two levels. The first level comprises person-year observations:

$$
Y_{i t}=\beta_{0 i}+\beta_{1 i} \log \left(a g e_{i t}\right)+\epsilon_{i t}
$$

Where $Y_{i t}$ is a person-specific, time-varying measure of rank in the age-specific family

\footnotetext{
${ }^{6}$ I focus on the temporal dimension of biological age rather than potential or actual work experience because my focus on family income complicates the relationship between years of work experience (real or potential) and family income among individuals with different degrees of labor force attachment.

${ }^{7}$ Results are identical in sign and significance in unweighted analyses, and substantively similar in the magnitude of the estimated coefficients.
} 
income distribution. Individual-and-time-specific deviations are captured by the error term $\epsilon_{i t}$ and are assumed to be iid with a conditional mean of 0 . The random coefficients $\beta_{0 i}$ and $\beta_{1 i}$ are allowed to vary across individuals and are modeled in the second level:

$$
\begin{aligned}
& \beta_{0 i}=\gamma_{00}+\gamma_{01} C N I, \text { White }_{i}+\gamma_{02} \text { CNI, } \text { Black }_{i}+\gamma_{03} \text { sex }_{i}+\mu_{0 i} \\
& \beta_{1 i}=\gamma_{10}+\gamma_{11} \text { CNI, } \text { White }_{i}+\gamma_{12} \text { CNI, } \text { Black }_{i}+\gamma_{13} \text { sex }_{i}+\mu_{1 i}
\end{aligned}
$$

Thus, the level 2 models estimate the person-specific income rank at age $25\left(\beta_{0 i}\right)$ and growth with age in relative income position $\left(\beta_{1 i}\right)$ as a function of group membership. The residual person-specific error terms capture individuals' deviations from their group averages in baseline income rank and relative income growth rates $\left(\mu_{0 i}\right.$ and $\mu_{1 i}$, respectively). I assume these residual, person-specific error terms to be identically distributed within groups, with the same variance and a mean of zero. I allow these unobserved residuals to be correlated.

The group-specific parameters (denoted with ) can be interpreted as group differences in the random coefficient of interest. For example, because the omitted group is the Latino children of immigrants, $\gamma_{01}$ is the difference in the average income rank at age 25 between children of White non-immigrants and children of Latino immigrants, and $\gamma_{11}$ is the difference in the average growth rate in family income between children of White non-immigrants and children of Latino immigrants. This parameterization ties the estimated coefficients and their associated significance tests to the primary research questions, which ask whether there are income disparities between children of Latino immigrants and children of White and Black non-immigrants, and, if so, whether these disparities increase or decrease over the life course.

In a subsequent model, I compare baseline income rank and relative income growth among individuals with parents at similar positions in the income distribution when they were adolescents. To do this, I include parental family income as a covariate in the level-2 equations predicting baseline income and income rank growth rates. This model tests whether income gaps between children of Latino immigrants and children 
of White non-immigrants can be attributed to different levels of economic background and whether income gaps between children of Latino immigrants and children of White non-immigrants conditional on parental income widen as these individuals age. In this parameterization, the coefficients on group membership represent the intergenerational penalty/premium for each group, relative to the children of Latino immigrants.

\section{Results: Baseline Models}

Table 2 displays the results from the baseline models. The first column shows results for the main outcome of interest: the age-specific rank in the family income distribution (a relative, rather than absolute measure of income over the life course). To compare the extent to which these patterns are driven by differences in relative vs. absolute mobility, the second column estimates the same model on an absolute outcome, log of family income. For these analyses, I add a constant $(5,000)$ to the entire sample to include individuals reporting zero family income before taking the log of family income.

For both outcomes, the first section shows the estimated differences in income rank at baseline (age 25) across groups. Consistent with expectations from the descriptive statistics, I find that at baseline, children of Black non-immigrants rank considerably lower in the age-specific distribution than children of Latino immigrants. While children of Latino immigrants rank, on average, slightly above the median of the family income distribution at age 25, children of Black non-immigrants rank, on average, at the 37th percentile. These differences in rank are considerable in dollar terms: while the mean family income among children of Latino immigrants is predicted to be around 56,000 dollars a year, the mean family income among children of Black non-immigrants is around 33,000 dollars a year, a difference of about 23,000 dollars a year. By comparison, children of White non-immigrants' average income rank is only slightly lower than the children of Latino immigrants, and the estimated difference in both the rank and absolute measures do not reach conventional levels of statistical significance.

The second section shows the estimated differences in relative growth rate across 
groups. The estimated coefficient for relative income growth over time in the reference group (children of Latino immigrants) is negative, suggesting that on average, the relative position among children of Latino immigrants in the family income distribution declines as they age. Children of Black non-immigrants lose ground at slightly lower rates than children of Latino immigrants, though this difference does not reach conventional levels of statistical significance. By contrast, children of White non-immigrants are predicted to gain relative ground in the age-specific income distribution as they age $(-1.713+$ $3.514=1.801)$, and the difference with the children of Latino immigrants is statistically significant.

I generate predicted average income rank trajectories from these models, visualized in Figure 1. This figure illustrates the importance of considering intragenerational dynamics when assessing group differences in economic position. The temporal patterns show that children of Latino immigrants increasingly lose ground relative to children of White nonimmigrants as they age, even though they start off, on average, at similar positions. While the average relative economic position among children of Latino immigrants declines when compared to the children of White non-immigrants, children of Latino immigrants do not tend to converge with children of Black non-immigrants over time. Rather, children of Latino immigrants start off with a higher relative position than children of Black nonimmigrants and, on average, maintain this relative advantage as they age.

Table 3 illustrates the magnitude of these gaps at different points in the observational period. The gap in average income rank among children of Latino immigrants and children of Black non-immigrants persists between 16 and 18 percentile points as a decade transpires. Over this same time period, the gap in average income rank between children of Latino immigrants and children of White non-immigrants reverses, from an almost 2 percentile point advantage at age 26 to a 7 percentile point disadvantage at age 37 . Given that the family income distribution widens as individuals age $\square^{8}$, these differences in average relative positions over the life course translate to growing inequalities in absolute

\footnotetext{
${ }^{8}$ Figure A1 in the appendix illustrates the growing spread of the family income distribution as individuals age: the difference between the 25 th and 75 th quintiles of the family income distribution increases by a nearly a third over a decade, from about 60,000 dollars at age 25 to 76,000 dollars at age 35 .
} 
income. The seven percentile-point gap between children of Latino immigrants and children of White non-immigrants at age 37 reflects a gap of 4759 dollars using the income distribution at age 25, but a gap of 6996 dollars using the income distribution at age 36 .

These results highlight the importance of analyzing economic positions as a timevarying construct when considering immigrants' economic mobility over time. Analyses that focus on whether immigrant offspring's economic positions have converged with those of non-immigrants obscure life course patterns of inequality when examining economic positions as a fixed outcome. In the following section, I test whether children of Latino immigrants experience an intergenerational penalty or premium by comparing children of Latino immigrants to the children of White and Black non-immigrants growing up in households situated at similar positions in the income distribution.

\section{Results: Intergenerational Models}

Table 4 assesses how children of Latino immigrants compare to children of White nonimmigrants who grew up with parents at similar positions in the income distribution. Parental income rank is measured on a 0-100 scale and is centered at the median of the income distribution. These results model individuals' baseline income and rank growth rate over $\log ($ age $)$ as a linear function of their parents' income and constrains this relationship to be equal across groups. In supplementary models, I show that allowing the linear relationship between parent income and offspring baseline income and income rank growth to vary by group does not substantively change the results (see Table 5 in the appendix).

I find that at age 25, after adjusting for parental income, children of Latino immigrants start off, on average, about 7 percentiles higher positions in the age-specific income distribution than children of White non-immigrants and 16 percentiles higher than children of Black non-immigrants. Unsurprisingly, children growing up in households higher in the income distribution also occupy higher positions in the age-specific income distribution at age 25: on average, a one-percentile increase in parental income is associated 
with about a .3 percentile increase in baseline income rank.

In the second half of the table, I assess the implications of parents' economic positions for their children's relative economic positions over early adulthood. Individuals from more advantaged households move slightly up in the age-specific family income distribution as they age. In other words, parental income is associated not only with higher family income levels, but with (slightly) more rapid growth in family income.

The children of White non-immigrants tend to grow up in households with higher levels of parental income. Because these results suggest that parental income is associated with both higher baseline income and income rank growth, differences in parental income between children of Latino immigrants and children of White non-immigrants explain a portion of the income gaps between the children of Latino immigrants and children of White non-immigrants over early adulthood. However, the results also show that children of White non-immigrants exhibit faster income rank growth conditional on parental income. Similar to the baseline results, the coefficients show that the children of Latino immigrants' relative position in the economic order declines slightly as they age.

These results are further illustrated in Figure 2, which shows the predicted average income ranks over early adulthood among men growing up with parents at the median of the income distribution in each group. These figures show that at early ages, children of Latino immigrants occupy a higher position in the age-specific family income distribution, on average, than the children of White and Black non-immigrants growing up in households with similar economic resources. However, this "intergenerational premium" for the children of Latino immigrants fades with age. By the mid-30s, children of White non-immigrants and children of Latino immigrants whose parents had comparable incomes have similar average family incomes. Note that as with the baseline models, though the children of Latino immigrants' relative position in the income distribution declines as they age, they do not, on average, move towards convergence in economic positions with the Black children of non-immigrants.

This figure reveals that our understanding of between-group differences in intergenerational mobility depends on when in the life course we assess outcomes. Focusing on 
earlier ages highlights an "intergenerational premium" among the children of Latino immigrants relative to the children of White and Black non-immigrants. Focusing on later ages suggests that "intergenerational penalties" in income between the children of Latino immigrants and the children of White non-immigrants are negligible. Both scenarios paint an optimistic picture for the long-term mobility prospects of the children of immigrants, but obscuring that immigrants' intergenerational premia decline over the life course of the offspring generation neglects an important temporal dimension of economic inequality.

Assessing the determinants of this declining intergenerational premium in relative income among children of Latino immigrants lies beyond the scope of this study. Nevertheless, some explanatory factors can be ruled out. Children of immigrants may be more likely to co-reside with their parents for longer and support them financially (Rumbaut and Komaie, 2010). If this is the case, then the intergenerational premium in relative income rank among the children of immigrants earlier in life may reflect the fact that they are more likely to co-reside with parents who also contribute to family income at earlier ages. Comparing the descriptive statistics among individuals who do not co-reside with their parents to those of the analytic sample suggests that parental co-residence contributes to the average income levels observed in the analytic sample, particularly among children of Latino immigrants (see Table 11 in the appendix). However, analyses excluding all individuals who co-reside with their parents suggest that parental co-residence drives only a small part of the decline in children of immigrants' intergenerational premium (see Table 12 in the appendix).

Putting together the results of the two models, I estimate the extent to which income gaps between children of Latino immigrants and children of White non-immigrants can be explained by differences in the levels of parental income, the extent to which these gaps are due to disparities conditional on parental income, and how these patterns vary by age. The results of these analyses are shown in Table 5 and visualized in Figure 3. The solid line in Figure 3 shows the predicted gap in income rank in the baseline model. This line demonstrating that the children of Latino immigrants slightly outrank the children 
of White non-immigrants early on. However, this income premium is quickly reversed to an income penalty which grows over time. The dashed line labeled "Gap Adjusting for Parental Income" shows that differences in parental income play a dominant role in the extent to which the children of White non-immigrants' advantages grow over time. When adjusting for parental income, the average income rank at age 26 among the children of Latino immigrants is about 7.5 percentiles larger than the average income rank among children of white immigrants growing up in similarly situated households (Table 5, column 3). By age 36, this "intergenerational premium" has eroded as the difference in average income rank between the two groups is close to zero.

However, differences in levels of parental income do not entirely explain how the relative advantage of the children of White non-immigrants over children of Latino immigrants grows over time. Differences in offspring's income conditional on parent income, also grow over time, if only slightly (from 5.65 to 6.86: see Table 5, column 4). Consistent with the literature on life cycle patterns in economics that find stronger intergenerational income persistence at later ages, these results suggest that growing returns to parental income over the life course explain an important degree of the reduction in the intergenerational income premium among the children of Latino immigrants. These results also indicate that children of White non-immigrants are doubly advantaged: while they tend to have higher-income parents, which is associated with higher rates of income growth, they also have higher rates of income growth conditional on parental income.

\section{Supplementary Analyses}

Though the NLSY97 is a contemporary, nationally representative sample observed from adolescence, the cohort is still in early adulthood. Sample members are in their late 30's by the latest observational period: thus, these analyses do not capture the full extent to which income dynamics over the life course shape our assessments of economic mobility over time. I conduct similar analyses using data from the NLSY79 following individuals 
through age 55 (See tables 13 and 14 in the appendix) 9 I find similar substantive results in this cohort and confirm that income gaps grow to a greater extent during early to middle adulthood than later in the life course. Though the sample sizes for the children of Latino immigrants are smaller and the children of Latino immigrants in earlier cohorts are likely to be different from the children of Latino immigrants in later cohorts due to changes in immigration policy, the substantive results are similar across cohorts.

While it is important to characterize economic assimilation among children of Latino immigrants as a whole, immigrants of the same ethnoracial group come from different national origins. Differences in both immigrant selection (Feliciano, 2005, Feliciano, 2020) and modes of incorporation (Portes and M. Zhou, 1993; Portes and Rumbaut, 2001) across national origins can be an important source of variation for individual outcomes, even within ethnoracial groups. I conduct a robustness check that limits the secondgeneration sample to the children of Mexican immigrants, the largest second-generation group by country of origin in the NLSY and a canonical example of immigrants facing less receptive modes of incorporation. These individuals comprise $74 \%$ of the children of Latino immigrants in the sample (see Table 10 in the appendix). I find similar substantive results as when including the children of all Latino immigrants. Data permitting, further research should extend the scope of these analyses to different cohorts spanning contemporary periods and examining immigrant descendants by national origin group.

\section{Discussion}

The extent to which immigrants and their descendants converge with non-immigrants in economic outcomes over time has been the subject of considerable debate, yet scholars primarily focus on whether immigrants' earnings converge with non-immigrants as they spend more time in the US or intergenerationally, by comparing the persistence of ethnic

\footnotetext{
${ }^{9}$ These analyses use the same functional form specification (Table 13, column 1 in the appendix), but also allow growth in rank income to vary by life stage by specifying a piecewise linear function with cutpoints at ages 30 and 36 (Table 13, column 2). This piecewise linear function allows for the possibility of growth deceleration (Cheng and Song, 2019), where income growth tapers off over middle adulthood. The interaction between group membership and the splines allows the rate of income growth at each spline to differ by group.
} 
gaps in socioeconomic outcomes across generations. These empirical strategies are used as evidence in favor of (or against) different theoretical models of immigrant assimilation, which posit convergence with non-immigrants over time or stagnation and even downward mobility over time.

Describing how patterns of individuals' positions in the income distribution change over the life course and comparing the children of Latino immigrants to the children of White and Black non-immigrants, I demonstrate the importance of a third temporal perspective: the life course of immigrant children themselves. These analyses integrate the sociological and demographic literatures on life course inequality and the multidisciplinary literature on immigrants' economic mobility over time.

I show that patterns of income growth within generations can dampen immigrants' progress over time. I find that children of Latino immigrants are making intergenerational gains relative to the children of Black and White non-immigrants: despite growing up in more disadvantaged households, children of Latino immigrants are, on average, in comparable economic positions to children of White non-immigrants at age 25, and considerably above the children of Black non-immigrants in the age-specific income distribution. However, as they age, children of Latino immigrants lose ground to the children of White non-immigrants (though not, in this cohort, to children of Black non-immigrants). This pattern suggests that, although average differences in economic outcomes between immigrants and non-immigrants can decline across generations, they can increase over the life course.

These results suggest that theoretical perspectives emphasizing steady progress across generations and emphasizing persistent inequality due to the nature of ethnoracial stratification in the United States both help to explain immigrants' economic mobility over time. Comparing individuals growing up in similarly situated households at the latest point of measurement (at age 36) shows that intergenerational mobility among the Latino children of immigrants is similar to intergenerational mobility among the children of White non-immigrants. These results support the contention that immigrant descendants make considerable intergenerational progress in economic outcomes across generations. How- 
ever, focusing on the story of intergenerational progress ignores that at least some of this progress is offset by growing inequality over the life course.

I do not find evidence that children of Latino immigrants experience, on average, "downward mobility" or "second generation decline." Nor do I find that children of Latino immigrants converge in economic outcomes with the children of Black non-immigrants over time. Nevertheless, I find that ethnoracial stratification matters for immigrants' economic mobility, as inequalities between children of Latino immigrants and children of White non-immigrants grow over the life course.

These analyses lay the groundwork for future research examining the mechanisms that put children of Latino immigrants at a disadvantage in income growth relative to children of White non-immigrants. I show that the children of Latino immigrants' disadvantage in parental income is one contributor to between-group income growth disparities. Future research might examine alternative measures of parental socioeconomic position, parental immigration status, and geographic position as additional determinants of intergenerational mobility and earnings growth. Future research might also consider trajectories in various components of family income. I show that men's hourly earnings follow patterns similar to family income (see Table 8, columns 3 and 4 in the appendix), but further research might consider the contributions of processes such as labor supply and household composition. Finally, group differences in income may arise due to group differences in the returns to income-relevant characteristics. Though supplementary analyses showed no evidence of group differences in the returns to parental income (see Table 6 in the Appendix), further research should consider the possibility that group differences in income trajectories are shaped by differential returns to other characteristics.

I show that the life course is one temporal dimension through which inequalities between immigrant and non-immigrant descendants can increase over time, contra temporal approaches that predict continuous progress towards economic convergence between immigrants and non-immigrants across generations. These results do not support the contention that, over time, children of Latino immigrants will converge in economic outcomes with children of Black non-immigrants: rather, the second generation retains an 
"advantage" relative to this group over time as they age. At the same time, these results show that children of Latino immigrants start off with an advantage relative to children of similarly situated White non-immigrants, but lose relative ground as they age. While these relative losses over the life course do not erase the intergenerational progress made from the parents' generation to the second generation, they highlight how relative economic positions shift both across and within immigrant generations. 


\section{References}

Abramitzky, Ran, Leah Platt Boustan, and Katherine Eriksson (2014). "A nation of immigrants: Assimilation and economic outcomes in the age of mass migration". In: Journal of Political Economy 122.3, pp. 467-506.

Abramitzky, Ran, Leah Platt Boustan, Elisa Jácome, et al. (2019). Intergenerational mobility of immigrants in the us over two centuries. Tech. rep. National Bureau of Economic Research.

Alba, Richard, Philip Kasinitz, and Mary C Waters (2011). "The kids are (mostly) alright: Second-generation assimilation: Comments on Haller, Portes and Lynch". In: Social Forces 89.3, pp. 763-773.

Alba, Richard D and Victor Nee (2009). Remaking the American mainstream: Assimilation and contemporary immigration. Harvard University Press.

Autor, David H, Lawrence F Katz, and Melissa S Kearney (2008). "Trends in US wage inequality: Revising the revisionists". In: The Review of economics and statistics 90.2 , pp. 300-323.

Bean, Frank D and Marta Tienda (1988). The hispanic population of the United States. Russell Sage Foundation.

Becker, Gary S and Nigel Tomes (1979). "An equilibrium theory of the distribution of income and intergenerational mobility". In: Journal of political Economy 87.6, pp. 1153-1189.

Blau, Peter M and Otis Dudley Duncan (1967). "The American occupational structure." In:

Bloome, Deirdre, Shauna Dyer, and Xiang Zhou (2018). "Educational inequality, educational expansion, and intergenerational income persistence in the United States". In: American Sociological Review 83.6, pp. 1215-1253.

Bloome, Deirdre and Jane Furey (2020). "Lifetime inequality: Income and occupational differences and dynamics in the US". In: Research in Social Stratification and Mobility 70, p. 100470.

Bonilla-Silva, Eduardo (2004). "From bi-racial to tri-racial: Towards a new system of racial stratification in the USA". In: Ethnic and racial studies 27.6, pp. 931-950.

Borjas, George J (1985). "Assimilation, changes in cohort quality, and the earnings of immigrants". In: Journal of labor Economics 3.4, pp. 463-489.

- (1989). "Economic theory and international migration". In: International migration review 23.3, pp. 457-485.

Breen, Richard, Richard Breen Jr, et al. (2004). Social mobility in Europe. Oxford University Press on Demand.

Catron, Peter (2016). "Made in America? Immigrant occupational mobility in the first half of the twentieth century". In: American Journal of Sociology 122.2, pp. 325-378.

- (2020). "The Melting-Pot Problem? The Persistence and Convergence of Premigration Socioeconomic Status During the Age of Mass Migration". In: Social Forces 99.1, pp. 366-397.

Cheng, Siwei (2014). "A life course trajectory framework for understanding the intracohort pattern of wage inequality". In: American Journal of Sociology 120.3, pp. 633700 .

Cheng, Siwei and Xi Song (2019). "Linked lives, linked trajectories: Intergenerational association of intragenerational income mobility". In: American Sociological Review 84.6, pp. 1037-1068. 
Cheng, Siwei, Christopher R Tamborini, et al. (2019). "Educational variations in cohort trends in the black-white earnings gap among men: Evidence from administrative earnings data". In: Demography 56.6, pp. 2253-2277.

Chetty, Raj et al. (2020). "Race and economic opportunity in the United States: An intergenerational perspective". In: The Quarterly Journal of Economics 135.2, pp. 711783.

Chiswick, Barry R and Paul W Miller (2009). "The international transferability of immigrants' human capital". In: Economics of Education Review 28.2, pp. 162-169.

DiPrete, Thomas A and Gregory M Eirich (2006). "Cumulative advantage as a mechanism for inequality: A review of theoretical and empirical developments". In: Annu. Rev. Sociol. 32, pp. 271-297.

Duncan, Otis Dudley et al. (1968). "Inheritance of poverty or inheritance of race?" In: On understanding poverty, pp. 85-110.

Feliciano, Cynthia (2005). "Does selective migration matter? Explaining ethnic disparities in educational attainment among immigrants' children". In: International migration review 39.4, pp. 841-871.

- (2020). "Immigrant selectivity effects on health, labor market, and educational outcomes". In: Annual Review of Sociology 46, pp. 315-334.

Gans, Herbert J (1992). "Second-generation decline: Scenarios for the economic and ethnic futures of the post-1965 American immigrants". In: Ethnic and racial studies 15.2, pp. 173-192.

Haider, Steven and Gary Solon (2006). "Life-cycle variation in the association between current and lifetime earnings". In: American economic review 96.4, pp. 1308-1320.

Han, JooHee (2020). "Does skin tone matter? Immigrant mobility in the US labor market". In: Demography 57.2, pp. 705-726.

Jarvis, Benjamin F and Xi Song (2017). "Rising intragenerational occupational mobility in the United States, 1969 to 2011". In: American sociological review 82.3, pp. 568599.

Kasinitz, Philip et al. (2009). Inheriting the city: The children of immigrants come of age. Russell Sage Foundation.

Killewald, Alexandra and Brielle Bryan (2018). "Falling behind: The role of inter-and intragenerational processes in widening racial and ethnic wealth gaps through early and middle adulthood". In: Social Forces 97.2, pp. 705-740.

Lee, Jennifer and Frank D Bean (2007). "Reinventing the color line immigration and America's new racial/ethnic divide". In: Social Forces 86.2, pp. 561-586.

Lubotsky, Darren (2007). "Chutes or ladders? A longitudinal analysis of immigrant earnings". In: Journal of Political Economy 115.5, pp. 820-867.

Mazumder, Bhashkar (2005). "Fortunate sons: New estimates of intergenerational mobility in the United States using social security earnings data". In: Review of Economics and Statistics 87.2, pp. 235-255.

Pfeffer, Fabian T and Alexandra Killewald (2019). "Intergenerational wealth mobility and racial inequality". In: Socius 5, p. 2378023119831799.

Portes, Alejandro and Rubén G Rumbaut (2001). Legacies: The story of the immigrant second generation. Univ of California Press.

Portes, Alejandro and Min Zhou (1993). "The new second generation: Segmented assimilation and its variants". In: The annals of the American academy of political and social science 530.1, pp. 74-96. 
Raudenbush, Stephen W and Anthony S Bryk (2002). Hierarchical linear models: Applications and data analysis methods. Vol. 1. sage.

Rumbaut, Rubén G and Golnaz Komaie (2010). "Immigration and adult transitions". In: The future of children, pp. 43-66.

Telles, Edward and Vilma Ortiz (2008). Generations of exclusion: Mexican-Americans, Assimilation, and Race. Russell Sage Foundation.

Tomaskovic-Devey, Donald, Melvin Thomas, and Kecia Johnson (2005). "Race and the accumulation of human capital across the career: A theoretical model and fixed-effects application". In: American Journal of Sociology 111.1, pp. 58-89.

Van Buuren, Stef and Karin Groothuis-Oudshoorn (2011). "mice: Multivariate imputation by chained equations in R". In: Journal of statistical software 45.1, pp. 1-67.

Villarreal, Andrés and Christopher R Tamborini (2018). "Immigrants' economic assimilation: Evidence from longitudinal earnings records". In: American Sociological Review 83.4, pp. $686-715$.

Ward, Zachary (2020). "The not-so-hot melting pot: The persistence of outcomes for descendants of the age of mass migration". In: American Economic Journal: Applied Economics 12.4, pp. 73-102.

Warner, William Lloyd and Leo Srole (1945). "The social systems of American ethnic groups." In: 
Table 1: Descriptive Statistics, NLSY97

\begin{tabular}{lrrrr}
\hline & Immigrant Offspring & & Non-Immigrant Offspring \\
\cline { 2 - 2 } & Latino & & White & Black \\
\hline Person-Year Observations & 3278 & 20316 & 10822 \\
Unique Individuals & 604 & 3777 & 2025 \\
Proportion Female & 47.5 & 48.9 & 49.4 \\
Family Income: & & & \\
25-28 & 76411.5 & 76227.1 & 47954.5 \\
$29-32$ & 76729.1 & 82894.0 & 46153.8 \\
$33-36$ & 82641.1 & 94739.1 & 50701.2 \\
Age-Specific Income Rank & & & \\
$25-28$ & 55.9 & 55.8 & 37.6 \\
$29-32$ & 54.1 & 57.2 & 35.6 \\
33-36 & 52.1 & 57.5 & 35.6 \\
Parent Income Rank & 44.8 & 59.1 & 35.8 \\
\hline
\end{tabular}

Table 2: Relative and Absolute Family Income over the Life Course

\begin{tabular}{lcc}
\hline & Age-Specific Rank & Log Family Income \\
\hline Coefficients predicting baseline rank $\beta_{0 i}:$ & & \\
Reference (Latino, Immigrant Offspring) & $55.128^{* * *}$ & $10.933^{* * *}$ \\
& $(1.460)$ & $(0.044)$ \\
Female & $1.632^{* *}$ & $0.061^{* * *}$ \\
White, Non-Immigrant Offspring & $(0.786)$ & $(0.023)$ \\
& -1.835 & -0.030 \\
Black, Non-Immigrant Offspring & $(1.491)$ & $(0.045)$ \\
& $-18.096^{* * *}$ & $-0.532^{* * *}$ \\
Coefficients predicting rank growth over log(age) $\beta_{1 i}:$ & $(1.605)$ & $(0.048)$ \\
Reference (Latino, Immigrant Offspring) & & \\
& $-1.713^{* *}$ & 0.012 \\
Female & $(0.790)$ & $(0.024)$ \\
White, Non-Immigrant Offspring & -0.590 & -0.011 \\
& $(0.407)$ & $(0.012)$ \\
Black, Non-Immigrant Offspring & $3.514^{* * *}$ & $0.094^{* * *}$ \\
& $(0.803)$ & $(0.025)$ \\
Observations & 0.544 & -0.023 \\
Log Likelihood & $(0.869)$ & $(0.027)$ \\
AIC & 34416 & 34416 \\
BIC & -156582.700 & -37244.910 \\
\hline$* * *$ p $<.01 ;{ }^{* *}$ p $<.05 ;{ }^{*}$ p $<.1$ & 313189.500 & 74513.820 \\
\end{tabular}

Table 3: Predicted Gaps in Income Rank, Children of Non-Immigrants - Children of Immigrant Latinos

\begin{tabular}{rrr}
\hline Age & White- Latino & Black- Latino \\
\hline 25 & -1.84 & -18.10 \\
29 & 3.82 & -17.22 \\
33 & 5.89 & -16.90 \\
36 & 6.90 & -16.74 \\
\hline
\end{tabular}


Table 4: Age-Specific Income Rank over the Life Course, cond. on Parent Income

\begin{tabular}{lc}
\hline & Age-Specific Rank \\
\hline Coefficients predicting baseline rank $\beta_{0 i}:$ & \\
Reference (Latino, Immigrant Offspring) & $57.368^{* * *}$ \\
Female & $(1.411)$ \\
& $2.653^{* * *}$ \\
White, Non-Immigrant Offspring & $(0.754)$ \\
& $-7.485^{* * *}$ \\
Black, Non-Immigrant Offspring & $(1.455)$ \\
& $-15.602^{* * *}$ \\
Parent Income Rank (median-centered) & $(1.552)$ \\
& $0.333^{* * *}$ \\
Coefficients predicting rank growth over log $\left(\right.$ age) $\beta_{1 i}:$ & $(0.014)$ \\
Reference (Latino, Immigrant Offspring) & \\
& \\
Female & $-1.603^{* *}$ \\
& $(0.787)$ \\
White, Non-Immigrant Offspring & -0.434 \\
& $(0.406)$ \\
Black, Non-Immigrant Offspring & $3.026^{* * *}$ \\
Parent Income Rank (median-centered) & $(0.808)$ \\
& 0.805 \\
Observations & $(0.867)$ \\
Log Likelihood & $0.031^{* * *}$ \\
BIC & $(0.008)$ \\
\hline$* * * p<.01 ;{ }^{* *}$ p $<.05 ;{ }^{*} p<.1$ & 34416 \\
& -155836.800 \\
& 311701.500 \\
& 311819.800 \\
\hline
\end{tabular}

Table 5: Rank Gap, Children of Non-Immigrant Whites and Children of Latino Immigrants

\begin{tabular}{rrrr}
\hline Age & Baseline Gap & Explained by Parental Income & Conditional on Parental Income \\
\hline 25 & -1.84 & -7.48 & 5.65 \\
26 & 0.60 & -5.39 & 5.99 \\
27 & 2.02 & -4.16 & 6.19 \\
28 & 3.04 & -3.29 & 6.33 \\
29 & 3.82 & -2.61 & 6.43 \\
30 & 4.46 & -2.06 & 6.52 \\
31 & 5.00 & -1.60 & 6.60 \\
32 & 5.47 & -1.19 & 6.66 \\
33 & 5.89 & -0.84 & 6.72 \\
34 & 6.26 & -0.52 & 6.77 \\
35 & 6.59 & -0.23 & 6.82 \\
36 & 6.90 & 0.03 & 6.86 \\
\hline
\end{tabular}




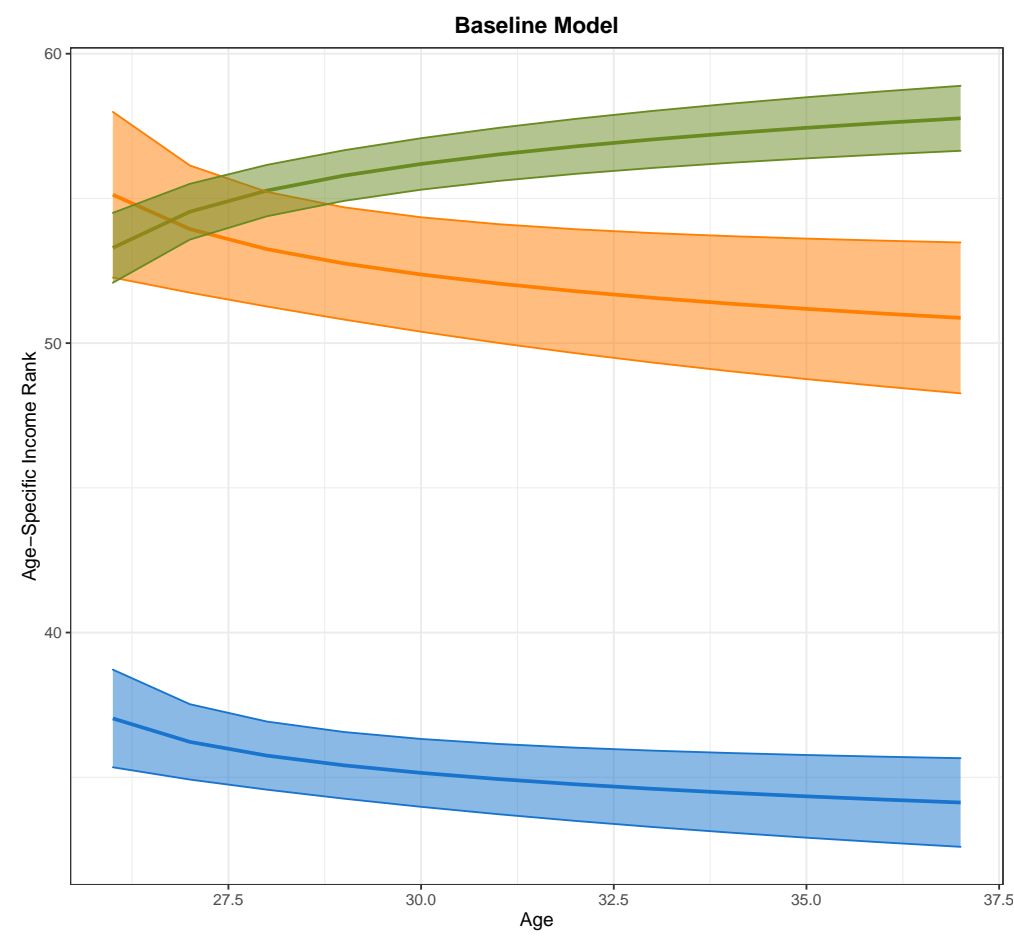

group $\square$ Children of Immigrant, Latino $\square$ Children of Non-Immigrant, Black $\square$ Children of Non-Immigrant, White

Figure 1

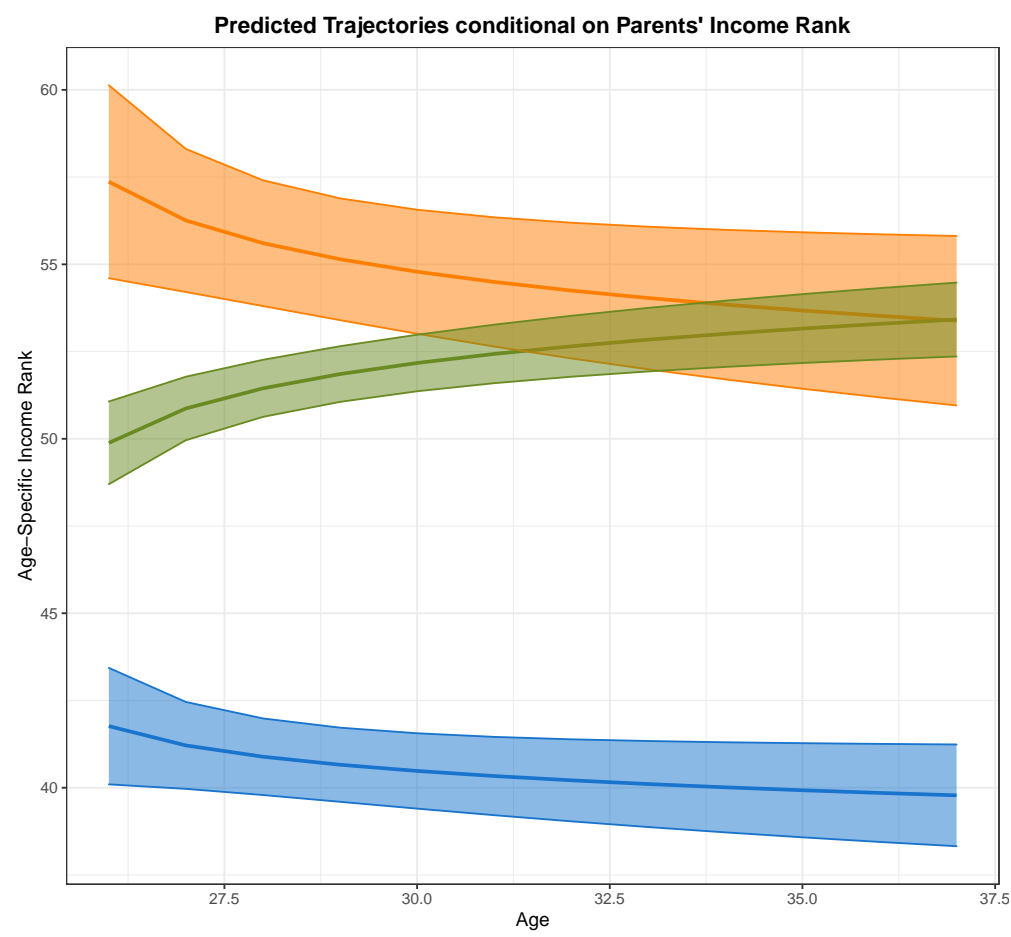

group $\square$ Children of Immigrant, Latino $\square$ Children of Non-Immigrant, Black $\square$ Children of Non-Immigrant, White

Figure 2 


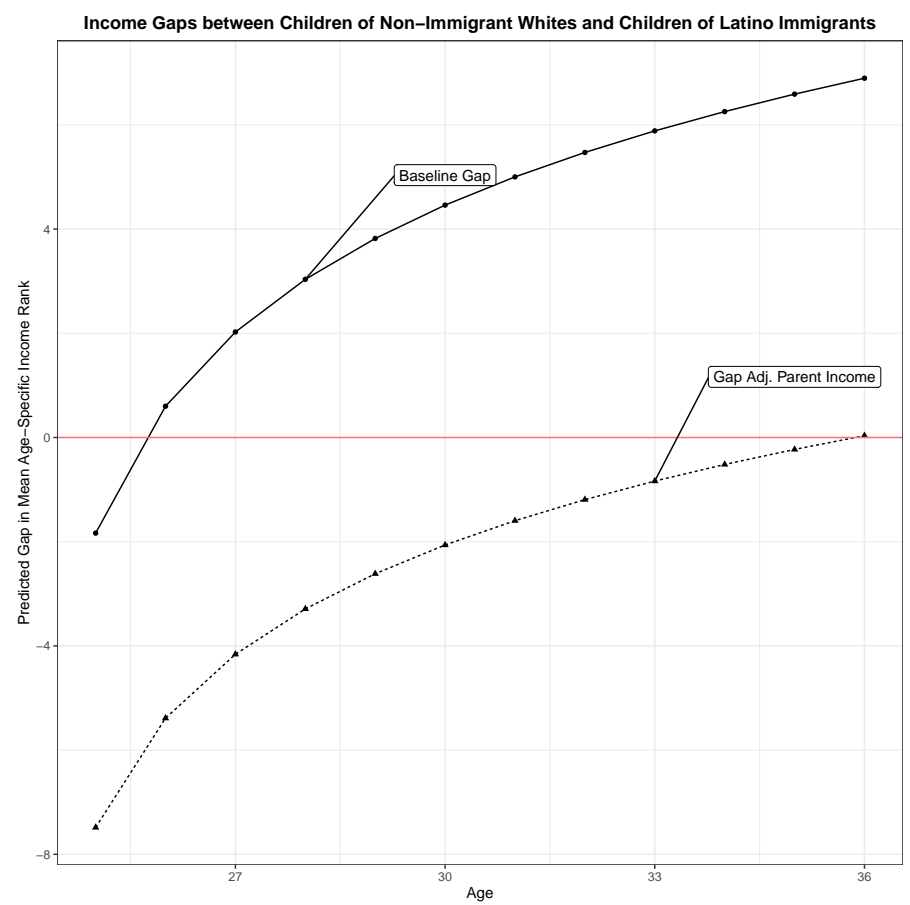

Figure 3 


\section{Appendix Tables \& Figures}

Table 6: Age-Specific Income Rank over the Life Course, cond. on Parent Income: allowing the slope on parental income to differ by group

\begin{tabular}{|c|c|c|}
\hline & \multicolumn{2}{|c|}{ Age-Specific Rank } \\
\hline \multicolumn{3}{|l|}{ Coefficients predicting baseline $\operatorname{rank} \beta_{0 i}$ : } \\
\hline Reference (Latino, Immigrant Offspring) & $\begin{array}{c}57.368^{* * *} \\
(1.411)\end{array}$ & $\begin{array}{c}57.563^{* * *} \\
(1.464)\end{array}$ \\
\hline Female & $\begin{array}{c}2.653^{* * *} \\
(0.754)\end{array}$ & $\begin{array}{c}2.692^{* * *} \\
(0.754)\end{array}$ \\
\hline Parent Income Rank (median-centered) & $\begin{array}{c}0.333^{* * *} \\
(0.014)\end{array}$ & $\begin{array}{c}0.361^{* * *} \\
(0.052)\end{array}$ \\
\hline White, Non-Immigrant Offspring & $\begin{array}{c}-7.485^{* * *} \\
(1.455)\end{array}$ & $\begin{array}{c}-7.303^{* * *} \\
(1.501)\end{array}$ \\
\hline White, Non-Immigrant Offspring * Parent Income Rank & & $\begin{array}{l}-0.076 \\
(0.055)\end{array}$ \\
\hline Black, Non-Immigrant Offspring & $\begin{array}{c}-15.602^{* * *} \\
(1.552)\end{array}$ & $\begin{array}{c}-13.935^{* * *} \\
(1.658)\end{array}$ \\
\hline Black, Non-Immigrant Offspring * Parent Income Rank & 0.092 & $(0.059)$ \\
\hline \multicolumn{3}{|l|}{ Coefficients predicting rank growth over $\log ($ age $) \beta_{1 i}$ : } \\
\hline Reference (Latino, Immigrant Offspring) & $\begin{array}{c}-1.603^{* *} \\
(0.787)\end{array}$ & $\begin{array}{c}-1.787^{* *} \\
(0.814)\end{array}$ \\
\hline Female & $\begin{array}{l}-0.434 \\
(0.406)\end{array}$ & $\begin{array}{l}-0.454 \\
(0.406)\end{array}$ \\
\hline Parent Income Rank (median-centered) & $\begin{array}{c}0.031^{* * *} \\
(0.008)\end{array}$ & $\begin{array}{c}0.005 \\
(0.029)\end{array}$ \\
\hline White, Non-Immigrant Offspring & $\begin{array}{c}3.026^{* * *} \\
(0.808)\end{array}$ & $\begin{array}{c}3.030^{* * * *} \\
(0.832)\end{array}$ \\
\hline White, Non-Immigrant Offspring * Parent Income Rank & & $\begin{array}{c}0.049 \\
(0.030)\end{array}$ \\
\hline Black, Non-Immigrant Offspring & $\begin{array}{c}0.805 \\
(0.867)\end{array}$ & $\begin{array}{c}0.071 \\
(0.922)\end{array}$ \\
\hline Black, Non-Immigrant Offspring * Parent Income Rank & & $\begin{array}{l}-0.034 \\
(0.033)\end{array}$ \\
\hline Observations & 34416 & 34416 \\
\hline Log Likelihood & -155836.800 & -155822.200 \\
\hline AIC & 311701.500 & 311680.400 \\
\hline $\mathrm{BIC}$ & 311819.800 & 311832.400 \\
\hline
\end{tabular}

${ }^{* * *} \mathrm{p}<.01 ;{ }^{* *} \mathrm{p}<.05 ;{ }^{*} \mathrm{p}<.1$ 
Table 7: Adjusting Family Income by Square Root of Family Size, then ranking

\begin{tabular}{|c|c|c|}
\hline & \multicolumn{2}{|c|}{ Age-Specific Rank, Family Income/Sqrt(Fam Size) } \\
\hline & Baseline & Cond. Parent Income \\
\hline \multicolumn{3}{|l|}{ Coefficients predicting baseline rank $\beta_{0 i}$ : } \\
\hline Reference (Latino, Immigrant Offspring) & $\begin{array}{c}51.896^{* * *} \\
(1.443)\end{array}$ & $\begin{array}{c}54.851^{* * *} \\
(1.421)\end{array}$ \\
\hline Parent Income Rank (median-centered) & & $\begin{array}{c}0.438^{* * *} \\
(0.051)\end{array}$ \\
\hline Female & $\begin{array}{c}0.201 \\
(0.776)\end{array}$ & $\begin{array}{l}1.400^{*} \\
(0.728)\end{array}$ \\
\hline White, Non-Immigrant Offspring & $\begin{array}{c}3.990^{* * *} \\
(1.473)\end{array}$ & $\begin{array}{c}-2.563^{*} \\
(1.456)\end{array}$ \\
\hline White, Non-Immigrant Offspring * Parent Income Rank & & $\begin{array}{c}-0.096^{*} \\
(0.053)\end{array}$ \\
\hline Black, Non-Immigrant Offspring & $\begin{array}{c}-14.176^{* * *} \\
(1.586)\end{array}$ & $\begin{array}{c}-10.086^{* * *} \\
(1.609)\end{array}$ \\
\hline Black, Non-Immigrant Offspring * Parent Income Rank & & $\begin{array}{c}0.050 \\
(0.057)\end{array}$ \\
\hline \multicolumn{3}{|l|}{ Coefficients predicting rank growth over $\log ($ age $) \beta_{1 i}$ : } \\
\hline Reference (Latino, Immigrant Offspring) & $\begin{array}{l}-0.797 \\
(0.763)\end{array}$ & $\begin{array}{l}-1.029 \\
(0.785)\end{array}$ \\
\hline Female & $\begin{array}{c}-0.840^{* *} \\
(0.390)\end{array}$ & $\begin{array}{c}-0.735^{*} \\
(0.388)\end{array}$ \\
\hline Parent Income Rank (median-centered) & & $\begin{array}{l}-0.018 \\
(0.028)\end{array}$ \\
\hline White, Non-Immigrant Offspring & $\begin{array}{l}1.848^{* *} \\
(0.775)\end{array}$ & $\begin{array}{l}1.680^{* *} \\
(0.801)\end{array}$ \\
\hline White, Non-Immigrant Offspring * Parent Income Rank & & $\begin{array}{l}0.055^{*} \\
(0.029)\end{array}$ \\
\hline Black, Non-Immigrant Offspring & $\begin{array}{c}0.138 \\
(0.840)\end{array}$ & $\begin{array}{l}-0.195 \\
(0.889)\end{array}$ \\
\hline Black, Non-Immigrant Offspring * Parent Income Rank & & $\begin{array}{l}-0.013 \\
(0.032) \\
\end{array}$ \\
\hline Observations & 34416 & 34416 \\
\hline Log Likelihood & -156314.300 & -155431.400 \\
\hline AIC & 312652.500 & 310898.800 \\
\hline BIC & 312753.900 & 311050.900 \\
\hline
\end{tabular}

${ }^{* * *} \mathrm{p}<.01 ;{ }^{* *} \mathrm{p}<.05 ;{ }^{*} \mathrm{p}<.1$ 
Table 8: Examining Absolute Income Measures: Total Family Income, Men's Hourly Earnings

\begin{tabular}{|c|c|c|c|c|}
\hline & \multicolumn{2}{|c|}{ Log Family Income } & \multicolumn{2}{|c|}{ Log Hourly Wage, Men } \\
\hline & Baseline & Cond. Parent Income & Baseline & Cond. Parent Income \\
\hline \multicolumn{5}{|l|}{ Coefficients predicting baseline rank $\beta_{0 i}$ : } \\
\hline Reference (Latino, Immigrant Offspring) & $\begin{array}{c}10.933^{* * *} \\
(0.044)\end{array}$ & $\begin{array}{c}11.001^{* * *} \\
(0.044)\end{array}$ & $\begin{array}{c}2.739^{* * *} \\
(0.040)\end{array}$ & $\begin{array}{c}2.768^{* * *} \\
(0.040)\end{array}$ \\
\hline Female & $\begin{array}{c}0.061^{* * *} \\
(0.023)\end{array}$ & $\begin{array}{c}0.091^{* * *} \\
(0.022)\end{array}$ & & \\
\hline Parent Income Rank (median-centered) & & $\begin{array}{c}0.010^{* * *} \\
(0.002)\end{array}$ & & $\begin{array}{c}0.004^{* * *} \\
(0.002)\end{array}$ \\
\hline White, Non-Immigrant Offspring & $\begin{array}{l}-0.030 \\
(0.045)\end{array}$ & $\begin{array}{c}-0.180^{* * *} \\
(0.045)\end{array}$ & $\begin{array}{l}-0.005 \\
(0.043)\end{array}$ & $\begin{array}{c}-0.086^{* *} \\
(0.043)\end{array}$ \\
\hline White, Non-Immigrant Offspring * Parent Income Rank & & $\begin{array}{l}-0.002 \\
(0.002)\end{array}$ & & $\begin{array}{c}0.001 \\
(0.002)\end{array}$ \\
\hline Black, Non-Immigrant Offspring & $\begin{array}{c}-0.532^{* * *} \\
(0.048)\end{array}$ & $\begin{array}{c}-0.399^{* * *} \\
(0.050)\end{array}$ & $\begin{array}{c}-0.209^{* * *} \\
(0.047)\end{array}$ & $\begin{array}{c}-0.168^{* * *} \\
(0.048)\end{array}$ \\
\hline Black, Non-Immigrant Offspring * Parent Income Rank & & $\begin{array}{l}0.004^{* *} \\
(0.002)\end{array}$ & & $\begin{array}{c}0.001 \\
(0.002)\end{array}$ \\
\hline \multicolumn{5}{|l|}{ Coefficients predicting rank growth over $\log ($ age $) \beta_{1 i}$ : } \\
\hline Reference (Latino, Immigrant Offspring) & $\begin{array}{c}0.012 \\
(0.024)\end{array}$ & $\begin{array}{c}0.012 \\
(0.025)\end{array}$ & $\begin{array}{c}0.078^{* * *} \\
(0.021)\end{array}$ & $\begin{array}{c}0.080^{* * * *} \\
(0.022)\end{array}$ \\
\hline Female & $\begin{array}{l}-0.011 \\
(0.012)\end{array}$ & $\begin{array}{l}-0.005 \\
(0.012)\end{array}$ & & \\
\hline Parent Income Rank (median-centered) & & $\begin{array}{c}0.001 \\
(0.001)\end{array}$ & & $\begin{array}{l}0.0005 \\
(0.001)\end{array}$ \\
\hline White, Non-Immigrant Offspring & $\begin{array}{c}0.094^{* * *} \\
(0.025)\end{array}$ & $\begin{array}{c}0.075^{* * *} \\
(0.026)\end{array}$ & $\begin{array}{l}0.054^{* *} \\
(0.022)\end{array}$ & $\begin{array}{l}0.044^{*} \\
(0.023)\end{array}$ \\
\hline White, Non-Immigrant Offspring * Parent Income Rank & & $\begin{array}{c}0.001 \\
(0.001)\end{array}$ & & $\begin{array}{l}0.0003 \\
(0.001)\end{array}$ \\
\hline Black, Non-Immigrant Offspring & $\begin{array}{l}-0.023 \\
(0.027)\end{array}$ & $\begin{array}{l}-0.027 \\
(0.028)\end{array}$ & $\begin{array}{l}-0.015 \\
(0.025)\end{array}$ & $\begin{array}{l}-0.013 \\
(0.026)\end{array}$ \\
\hline Black, Non-Immigrant Offspring * Parent Income Rank & & $\begin{array}{l}-0.001 \\
(0.001)\end{array}$ & & $\begin{array}{c}-0.0001 \\
(0.001)\end{array}$ \\
\hline Observations & 34416 & 34416 & 15004 & 15004 \\
\hline Log Likelihood & -37244.910 & -36528.660 & -9618.216 & -9443.077 \\
\hline AIC & 74513.820 & 73093.330 & 19256.430 & 18918.150 \\
\hline $\mathrm{BIC}$ & 74615.170 & 73245.360 & 19332.590 & 19040.010 \\
\hline
\end{tabular}


Table 9: Changing the Functional Form Specification for Age-Income Rank: Linear, Quadratic

Age-Specific Rank

Linear Quadratic

Coefficients predicting baseline rank $\beta_{0 i}$ :

Reference (Latino, Immigrant Offspring)

$54.491^{* * *}$

$49.959^{* * *}$

Female

$1.688^{* * *}$

$1.687^{* * *}$

$(0.652)$

(0.651)

White, Non-Immigrant Offspring

$-0.092$

$-0.088$

Black, Non-Immigrant Offspring

$-18.492^{* * *}$

$-18.498^{* * *}$

$(1.315)$

Coefficients predicting rank growth over time $\beta_{1 i}$ :

Reference (Latino, Immigrant Offspring)

$\begin{array}{cc}-0.437^{* *} & -0.869^{* *} \\ (0.173) & (0.378)\end{array}$

Female

$-0.219^{* *}$

$-0.220^{* *}$

White, Non-Immigrant Offspring

(0.086)

$(0.086)$

$0.782^{* * *}$

$0.780^{* * *}$

Black, Non-Immigrant Offspring

(0.175)

$(0.175)$

0.292

0.291

(0.190)

$(0.190)$

Age Squared (holding fixed across groups)

(0.006)

\begin{tabular}{lcc}
\hline Observations & 34416 & 34416 \\
Log Likelihood & -156589.000 & -156588.200 \\
AIC & 313202.000 & 313202.300 \\
BIC & 313303.400 & 313312.100 \\
\hline${ }^{* * *} \mathrm{p}<.01 ;{ }^{* *} \mathrm{p}<.05 ;{ }^{*} \mathrm{p}<.1$ & &
\end{tabular}


Table 10: Restricting Second Generation Group to Mexican/Central American Origins

\begin{tabular}{|c|c|c|}
\hline & \multicolumn{2}{|c|}{ Age-Specific Rank } \\
\hline & Baseline & Cond. Parent Income \\
\hline \multicolumn{3}{|l|}{ Coefficients predicting baseline rank $\beta_{0 i}$ : } \\
\hline Reference (Latino, Immigrant Offspring) & $\begin{array}{c}55.751^{* * *} \\
(1.702)\end{array}$ & $\begin{array}{c}58.554^{* * *} \\
(1.791)\end{array}$ \\
\hline Female & $\begin{array}{l}1.616^{* *} \\
(0.796)\end{array}$ & $\begin{array}{c}2.671^{* * *} \\
(0.762)\end{array}$ \\
\hline Parent Income Rank (median-centered) & & $\begin{array}{c}0.303^{* * *} \\
(0.065)\end{array}$ \\
\hline White, Non-Immigrant Offspring & $\begin{array}{l}-2.452 \\
(1.726)\end{array}$ & $\begin{array}{c}-8.282^{* * *} \\
(1.820)\end{array}$ \\
\hline White, Non-Immigrant Offspring * Parent Income Rank & & $\begin{array}{l}-0.018 \\
(0.068)\end{array}$ \\
\hline Black, Non-Immigrant Offspring & $\begin{array}{c}-18.712^{* * *} \\
(1.826)\end{array}$ & $\begin{array}{c}-14.915^{* * *} \\
(1.951)\end{array}$ \\
\hline Black, Non-Immigrant Offspring * Parent Income Rank & & $\begin{array}{l}0.150^{* *} \\
(0.071)\end{array}$ \\
\hline \multicolumn{3}{|l|}{ Coefficients predicting rank growth over $\log ($ age $) \beta_{1 i}$ : } \\
\hline Reference (Latino, Immigrant Offspring) & $\begin{array}{c}-2.558^{* * *} \\
(0.925)\end{array}$ & $\begin{array}{c}-2.540^{* *} \\
(1.000)\end{array}$ \\
\hline Female & $\begin{array}{l}-0.555 \\
(0.413)\end{array}$ & $\begin{array}{l}-0.418 \\
(0.410)\end{array}$ \\
\hline Parent Income Rank (median-centered) & & $\begin{array}{c}0.015 \\
(0.036)\end{array}$ \\
\hline White, Non-Immigrant Offspring & $\begin{array}{c}4.343^{* * *} \\
(0.934)\end{array}$ & $\begin{array}{c}3.764^{* * *} \\
(1.012)\end{array}$ \\
\hline White, Non-Immigrant Offspring * Parent Income Rank & & $\begin{array}{c}0.039 \\
(0.038)\end{array}$ \\
\hline Black, Non-Immigrant Offspring & $\begin{array}{c}1.373 \\
(0.991)\end{array}$ & $\begin{array}{c}0.806 \\
(1.088)\end{array}$ \\
\hline Black, Non-Immigrant Offspring * Parent Income Rank & & $\begin{array}{c}-0.043 \\
(0.040)\end{array}$ \\
\hline$\overline{\text { Observations }}$ & 33592 & 33592 \\
\hline Log Likelihood & -152748.700 & -152016.600 \\
\hline $\mathrm{AIC}$ & 305521.500 & 304069.200 \\
\hline $\mathrm{BIC}$ & 305622.500 & 304220.800 \\
\hline
\end{tabular}

${ }^{* * *} \mathrm{p}<.01 ;{ }^{* *} \mathrm{p}<.05 ;{ }^{*} \mathrm{p}<.1$ 


\section{Excluding Parental Co-residence}

Table 11: Descriptive Statistics, NLSY97

\begin{tabular}{lrrrr}
\hline & \multicolumn{2}{c}{ Immigrant Offspring } & & Non-Immigrant Offspring \\
\cline { 5 - 5 } & Latino & & White & Black \\
\hline Person-Year Observations & 2244 & & 17184 & 8209 \\
Unique Individuals & 524 & 3575 & 1840 \\
Proportion Female & 52.14 & 50.36 & 51.03 \\
Family Income: & & & \\
25-28 & 68774.42 & 71960.32 & 43532.86 \\
$29-32$ & 72294.04 & 82135.29 & 44537.43 \\
$33-36$ & 80167.17 & 95518.02 & 49933.08 \\
Age-Specific Income Rank & & & \\
$25-28$ & 53.19 & 54.45 & 35.33 \\
$29-32$ & 53.37 & 57.31 & 35.01 \\
33-36 & 52.00 & 58.17 & 35.74 \\
Parent Income Rank & 0.44 & 0.59 & 0.36 \\
\hline
\end{tabular}

Table 12: Restricting Sample to those not Co-residing with Parents

\begin{tabular}{lcc}
\hline & \multicolumn{2}{c}{ Age-Specific Rank } \\
& Baseline & Cond. Parent Income \\
\hline Coefficients predicting baseline rank $\beta_{0 i}:$ & & \\
Reference (Latino, Immigrant Offspring) & $51.605^{* * *}$ & $53.799^{* * *}$ \\
& $(1.729)$ & $(1.690)$ \\
Female & $2.573^{* * *}$ & $3.426^{* * *}$ \\
& $(0.841)$ & $(0.817)$ \\
Parent Income Rank (median-centered) & & $0.286^{* * *}$ \\
White, Non-Immigrant Offspring & -1.077 & $(0.015)$ \\
& $(1.747)$ & $-6.177^{* * *}$ \\
Black, Non-Immigrant Offspring & $-18.629^{* * *}$ & $(1.723)$ \\
& $(1.879)$ & $(1.837)$ \\
Coefficients predicting rank growth over log(age) $\beta_{1 i}:$ & & \\
Reference (Latino, Immigrant Offspring) & -0.076 & 0.103 \\
Female & $(0.940)$ & $(0.933)$ \\
Parent Income Rank (median-centered) & $-1.174^{* * *}$ & $-0.973^{* *}$ \\
White, Non-Immigrant Offspring & $(0.440)$ & $(0.437)$ \\
Black, Non-Immigrant Offspring & & $0.052^{* * *}$ \\
& & $(0.008)$ \\
Observations & $3.203^{* * *}$ & $2.383^{* *}$ \\
Log Likelihood & $(0.947)$ & $(0.948)$ \\
BIC & 0.823 & 1.284 \\
\hline
\end{tabular}

${ }^{* * *} \mathrm{p}<.01 ;{ }^{* *} \mathrm{p}<.05 ;{ }^{*} \mathrm{p}<.1$ 


\section{Supplementary Results: NLSY79}

Table 13: NLSY79

\begin{tabular}{|c|c|c|}
\hline & \multicolumn{2}{|c|}{ Age-Specific Family Income Rank } \\
\hline & Log(Age) & Linear Splines \\
\hline \multicolumn{3}{|l|}{ Coefficients predicting baseline rank $\beta_{0 i}$ : } \\
\hline Reference (Latino, Immigrant Offspring) & $\begin{array}{c}50.393^{* * *} \\
(1.034)\end{array}$ & $\begin{array}{c}50.483^{* * *} \\
(0.882)\end{array}$ \\
\hline Female & $\begin{array}{c}-1.001^{*} \\
(0.599)\end{array}$ & $\begin{array}{c}-1.560^{* * *} \\
(0.547)\end{array}$ \\
\hline White, Non-Immigrant Offspring & $\begin{array}{c}4.390^{* * *} \\
(1.057)\end{array}$ & $\begin{array}{c}3.751^{* * * *} \\
(0.906)\end{array}$ \\
\hline Black, Non-Immigrant Offspring & $\begin{array}{c}-7.989^{* * *} \\
(1.143)\end{array}$ & $\begin{array}{c}-7.508^{* * *} \\
(0.979)\end{array}$ \\
\hline \multicolumn{3}{|c|}{ Coefficients predicting rank growth over $\log ($ age $) \beta_{1 i}$ : } \\
\hline Reference (Latino, Immigrant Offspring) & $\begin{array}{l}-0.296 \\
(0.389)\end{array}$ & \\
\hline Female & $\begin{array}{l}-0.267 \\
(0.226)\end{array}$ & \\
\hline White, Non-Immigrant Offspring & $\begin{array}{c}1.311^{* * *} \\
(0.398)\end{array}$ & \\
\hline Black, Non-Immigrant Offspring & $\begin{array}{c}-1.019^{* *} \\
(0.428)\end{array}$ & \\
\hline \multicolumn{3}{|c|}{ Coefficients predicting rank growth over linear spline (25-30) $\beta_{1 i}$ : } \\
\hline Reference (Latino, Immigrant Offspring) & & $\begin{array}{l}-0.159 \\
(0.124)\end{array}$ \\
\hline Female & & $\begin{array}{c}0.098 \\
(0.080)\end{array}$ \\
\hline White, Non-Immigrant Offspring & & $\begin{array}{c}0.469^{* * *} \\
(0.128)\end{array}$ \\
\hline Black, Non-Immigrant Offspring & & $\begin{array}{c}-0.548^{* * *} \\
(0.137)\end{array}$ \\
\hline \multicolumn{3}{|c|}{ Coefficients predicting rank growth over linear spline (31-36) $\beta_{2 i}$ : } \\
\hline Reference (Latino, Immigrant Offspring) & & $\begin{array}{l}-0.072 \\
(0.073)\end{array}$ \\
\hline Female & & $\begin{array}{c}-0.083^{*} \\
(0.049)\end{array}$ \\
\hline White, Non-Immigrant Offspring & & $\begin{array}{c}0.281^{* * *} \\
(0.076)\end{array}$ \\
\hline Black, Non-Immigrant Offspring & & $\begin{array}{c}0.034 \\
(0.080)\end{array}$ \\
\hline \multicolumn{3}{|c|}{ Coefficients predicting rank growth over linear spline $(37-55) \beta_{3 i}$ : } \\
\hline Reference (Latino, Immigrant Offspring) & & $\begin{array}{l}0.096^{* *} \\
(0.038)\end{array}$ \\
\hline Female & & $\begin{array}{l}-0.042 \\
(0.025)\end{array}$ \\
\hline White, Non-Immigrant Offspring & & $\begin{array}{c}-0.095^{* *} \\
(0.040)\end{array}$ \\
\hline Black, Non-Immigrant Offspring & & $\begin{array}{l}-0.054 \\
(0.042)\end{array}$ \\
\hline Observations & 140169 & 140169 \\
\hline Log Likelihood & -624285.500 & -606726.800 \\
\hline $\mathrm{AIC}$ & 1248595.000 & 1213494.000 \\
\hline $\mathrm{BIC}$ & 1248713.000 & 1213691.000 \\
\hline
\end{tabular}

${ }^{* * *} \mathrm{p}<.01 ;{ }^{* *} \mathrm{p}<.05 ;{ }^{*} \mathrm{p}<.1$ 
Table 14: NLSY79, Baseline + Conditional on Parent Income Models

\begin{tabular}{|c|c|c|}
\hline & \multicolumn{2}{|c|}{ Age-Specific Family Income Rank } \\
\hline & Baseline & Cond. Parent Income \\
\hline \multicolumn{3}{|l|}{ Coefficients predicting baseline rank $\beta_{0 i}$ : } \\
\hline Reference (Latino, Immigrant Offspring) & $\begin{array}{c}50.657^{* * *} \\
(1.115)\end{array}$ & $\begin{array}{c}50.911^{* * *} \\
(1.059)\end{array}$ \\
\hline Parent Income Rank (median-centered) & & $\begin{array}{c}0.377^{* * *} \\
(0.012)\end{array}$ \\
\hline Female & $\begin{array}{l}-0.425 \\
(0.669)\end{array}$ & $\begin{array}{c}0.165 \\
(0.630)\end{array}$ \\
\hline White, Non-Immigrant Offspring & $\begin{array}{c}4.402^{* * *} \\
(1.147)\end{array}$ & $\begin{array}{c}0.173 \\
(1.098)\end{array}$ \\
\hline Black, Non-Immigrant Offspring & $\begin{array}{c}-8.295^{* * *} \\
(1.229)\end{array}$ & $\begin{array}{c}-3.908^{* * *} \\
(1.174)\end{array}$ \\
\hline \multicolumn{3}{|c|}{ Coefficients predicting rank growth over $\log ($ age $) \beta_{1 i}$ : } \\
\hline Reference (Latino, Immigrant Offspring) & $\begin{array}{c}-0.691^{*} \\
(0.416)\end{array}$ & $\begin{array}{l}-0.682 \\
(0.415)\end{array}$ \\
\hline Parent Income Rank (median-centered) & & $\begin{array}{c}-0.017^{* * *} \\
(0.005)\end{array}$ \\
\hline Female & $\begin{array}{c}-0.044 \\
(0.248)\end{array}$ & $\begin{array}{l}-0.054 \\
(0.247)\end{array}$ \\
\hline White, Non-Immigrant Offspring & $\begin{array}{c}1.318^{* * *} \\
(0.429)\end{array}$ & $\begin{array}{c}1.289^{* * *} \\
(0.433)\end{array}$ \\
\hline Black, Non-Immigrant Offspring & $\begin{array}{c}-0.988^{* *} \\
(0.457)\end{array}$ & $\begin{array}{c}-1.198^{* * *} \\
(0.458)\end{array}$ \\
\hline Observations & 114868 & 114868 \\
\hline Log Likelihood & -510650.800 & -509866.100 \\
\hline AIC & 1021326.000 & 1019760.000 \\
\hline $\mathrm{BIC}$ & 1021441.000 & 1019895.000 \\
\hline
\end{tabular}

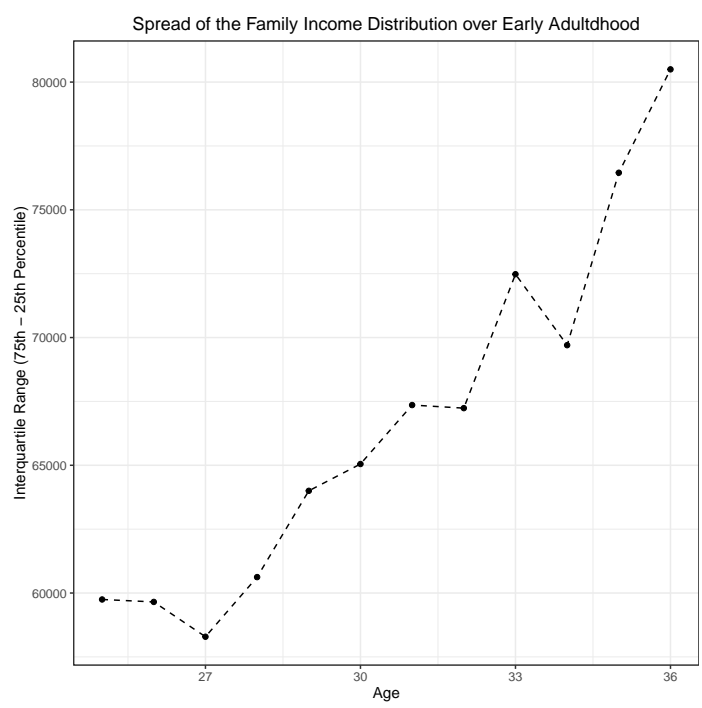

Figure A1 